\title{
Pre-clinical development of a vaccine against Lassa fever
}

\author{
L Banadyga ${ }^{1}$, DR Stein ${ }^{1,2}$, X Qiu ${ }^{1,2}$, D Safronetz ${ }^{1,2 *}$
}

\begin{abstract}
Lassa virus (LASV) is a persistent global health threat that causes about half a million cases of Lassa fever each year in Western Africa. Although most cases are mild, the disease can cause significant morbidity and results in as many as 5,000 deaths per year. Since 2015 , Nigeria has been experiencing a severe and extended outbreak of Lassa fever, raising concerns that it could spill over into other countries and reach a magnitude similar to the West African Ebola outbreak of 2013-2016. Despite the burden that Lassa fever places on public health, both in Africa and around the world, there are still no clinically-approved therapeutics or vaccines to treat or prevent it. Nevertheless, a number of promising candidate vaccines have been developed over the last several years, and there is a growing political and social determination to drive at least one of these candidates towards licensure.

This paper describes a LASV vaccine candidate that is being developed at Canada's National Microbiology Laboratory. Based on the same live attenuated vesicular stomatitis virus (VSV) vaccine platform that was used to produce the successful Ebola virus vaccine, the VSV-based LASV vaccine has been shown to elicit a potent and protective immune response against LASV. The vaccine shows $100 \%$ protection in the "gold-standard" nonhuman primate model of Lassa fever, inducing both humoral and cellular immune responses. Moreover, studies have shown that a single vaccination may offer universal protection against numerous different strains of the virus, and additional studies have shown that immunization with the VSV platform appears to be unaffected by pre-existing immunity to VSV. The next step in the development of the VSV-based LASV vaccine is phase I human clinical trials to assess vaccine safety and dosage.
\end{abstract}

Suggested citation: Banadyga L, Stein DR, Qiu X, Safronetz D. Pre-clinical development of a vaccine against Lassa fever. Can Commun Dis Rep 2018;44(6):139-47. https://doi.org/10.14745/ccdr.v44i06a04

Keywords: Lassa virus; Lassa fever; vesicular stomatitis virus; vaccine; pre-clinical development

\author{
Affiliations \\ 1 Zoonotic Diseases and Special \\ Pathogens Program, National \\ Microbiology Laboratory, Public \\ Health Agency of Canada, \\ Winnipeg, MB \\ ${ }^{2}$ Department of Medical \\ Microbiology and Infectious \\ Diseases, University of Manitoba, \\ Winnipeg, MB
}

*Correspondence: david. safronetz@canada.ca

\section{Introduction}

The 2013-2016 Ebola virus (EBOV) outbreak in Western Africa demonstrated that an outbreak anywhere could pose a threat everywhere (1). With nearly 29,000 cases and over 11,000 deaths, EBOV ravaged the countries of Sierra Leone, Liberia and Guinea, and the disease was ultimately exported to numerous neighbouring countries and some Western nations, including the United States (US) (2). Moreover, the outbreak not only devastated the public health infrastructure of Western Africa, but it also strained the global health response. Thousands of health care workers from around the world were deployed to Western Africa where they suffered a disproportionate burden, and over $50 \%$ of those infected with EBOV succumbed to the disease (3). At least part of the reason for the magnitude and severity of this outbreak was the lack of a clinically-approved treatment or a vaccine to prevent it.

In the wake of the EBOV outbreak, as well as the Zika virus outbreak that followed in 2015, the Bill and Melinda Gates Foundation recognized a global need for advanced epidemic preparedness. In collaboration with the Wellcome Trust, the World Economic Forum, and the governments of Norway and India, the Bill and Melinda Gates Foundation co-founded the
Coalition for Epidemic Preparedness and Innovations in 2016. The main objective of this coalition was to fund the development of promising vaccines for emerging pathogens that may cause significant outbreaks in the near future, with the goal of rapid scale-up into phase III clinical trials in the event of an outbreak. One of the pathogens selected for accelerated funding and development by this Coalition was Lassa virus (LASV).

Lassa virus, an enveloped, single-stranded, ribonucleic acid (RNA) virus from the family Arenaviridae, is the causative agent of the viral hemorrhagic fever known as Lassa fever. Typically, the virus is transmitted from exposure to the urine or feces of infected Mastomys rats, although it may also be spread from human to human through direct contact with infected blood, urine, feces or other bodily secretions. Following an incubation period of one to three weeks, the disease is marked by the gradual onset of fever, malaise, and muscle and joint pain. As the disease progresses, fever and myalgia worsen, and patients may become prostrate. Diarrhea, vomiting and other gastrointestinal disturbances are common, as are retrosternal pain and cough. Hemorrhagic manifestations are uncommon but an indication of a poor prognosis, as is facial edema and pleural effusions. 
Fatal cases culminate in shock and death, whereas nonfatal cases resolve over the course of two to three weeks, during which deafness is common and often permanent (4).

Approximately 300,000 to 500,000 cases of Lassa fever occur in West Africa each year, making it one of the most prevalent viral hemorrhagic fevers in humans $(5,6)$. Although typically only $1-2 \%$ of these cases are fatal, the scale of infections pushes the overall number of fatalities up to several thousand per year. Cases of Lassa fever are mainly restricted to the West African countries of Sierra Leone, Liberia, Guinea, and Nigeria; however, imported cases of LASV have been extensively documented, along with human-to-human transmission (7-10). Since 2015, Nigeria has been suffering a prolonged outbreak of Lassa fever, sparking fears of another epidemic that may rival the scope of the recent West African EBOV outbreak. Since the beginning of 2018, LASV has resulted in thousands of suspected cases, 413 confirmed cases, nine probable cases and 114 deaths. Based on confirmed and probable cases, the Nigerian outbreak has had a remarkably high case fatality rate of $25 \%$ (11).

Despite the significant burden that LASV places on global public health, the virus remains understudied, with no approved treatment or vaccine. Nevertheless, several candidate LASV vaccines have been identified and await further clinical development, including the LASV vaccine that is under development at Canada's National Microbiology Laboratory (NML). This vaccine is a replication-competent vesicular stomatitis virus (VSV)-based vaccine that has shown remarkable efficacy in LASV disease animal models. In this overview, we discuss the pre-clinical development of the VSV-based LASV vaccine, placing it in the context of the EBOV vaccine that was developed from the same VSV vaccine platform, and we describe some other promising LASV vaccine candidates.

\section{Background}

\section{Vesicular stomatitis virus as a vaccine platform}

The most effective vaccines against viruses usually use a live attenuated virus. Live attenuated vaccines, such as the measles vaccine, are often more effective at inducing protective immune responses and durable immunity than killed virus vaccines or subunit vaccines. One approach to generating live attenuated vaccines has relied on using a relatively harmless "backbone" virus as a vaccine platform to carry antigens from another, more pathogenic virus. At the NML, we have been working with VSV as a vaccine platform for a variety of different viruses, including EBOV, Marburg virus (MARV) and LASV.

Vesiculoviruses comprise their own genus within the family Rhabdoviridae and cause disease primarily in mammals and fish (12). In the Western hemisphere, two vesiculoviruses predominate: vesicular stomatitis Indiana virus; and vesicular stomatitis New Jersey virus (13). Both VSVs are insect-vectored viruses that cause vesicular stomatitis in horses, cattle and swine and cause erosive lesions on the tongue, gums, lips, hooves and teats of infected animals (14). In humans, VSV infection is also possible, although infrequent, and can lead to a self-limiting, influenza-like illness with or without the presentation of vesicular lesions (15-17). Because of the similarity in presentation to foot-and-mouth disease in livestock and agricultural animals,
VSV is considered a reportable disease by the Government of Canada.

The development of a system to engineer de novo recombinant VSV from DNA plasmids $(18,19)$ greatly increased the utility of VSV as a vaccine delivery platform (20). Wild type VSV already possessed several qualities that made it a suitable vaccine vector and the ability to engineer recombinant VSV only increased its usefulness. The VSV genome has the capacity to tolerate the addition of large and multiple transgenes, which serve as vaccine antigens $(21,22)$, and the virus itself is capable of replicating to high titers in a variety of cell types (23-25), thus ensuring the ease of vaccine production. Moreover, infection with VSV induces a strong humoral and cellular response (26-28), thereby promoting a robust immune response against the incorporated transgene, and pre-existing immunity in humans is rare (15-17), thereby maximizing the vaccine's effectiveness. Additionally, VSV replicates in the cytoplasm without a DNA intermediate, which precludes the possibility of genetic recombination with the host cell, and the VSV genome is non-segmented, which precludes the possibility of genetic shift. Thus, given the potential for VSV to serve as a safe and effective vaccine vector, it is not surprising that this system has been widely exploited to develop vaccines against numerous viruses, including HIV, for which "first-inhuman" evaluations have already been completed (29).

A notable variation of the VSV vaccine platform employed by the NML is known as VSV $\triangle \mathrm{G}$ because it lacks the viral glycoprotein (G), which enables virus entry and serves as the virus's major pathogenicity factor. The removal of VSV G not only attenuates the virus by eliminating its potential to infect the nervous system, but it also provides the opportunity to substitute in an analogous viral glycoprotein, thus directing a potent immune response towards an important antigenic target. This strategy was used to develop the highly successful VSV-based EBOV vaccine, which recently demonstrated $100 \%$ efficacy against EBOV disease in a small phase III clinical trial (30). Our work at the NML on the LASV vaccine is built on the same VSV $\triangle \mathrm{G}$ backbone (Figure 1).

\section{Development of vesicular stomatitis virus-based Ebola and Lassa fever vaccines}

The development of the VSV-based vaccine against LASV has been closely associated with the development of the VSV-EBOV vaccine. The origins of both vaccines can be traced to a single publication. In 2004, Garbutt and colleagues published the first report of replication-competent VSVs (serotype Indiana; VSIV) expressing the glycoproteins of EBOV, MARV or LASV, referred to as VSV-EBOV, VSV-MARV and VSV-LASV, respectively (31). All three viruses exhibited slightly attenuated growth kinetics compared with wild type VSV, and all three viruses exhibited robust expression of their glycoprotein, as well as the expected proteolytic processing patterns. Moreover, none of these VSVs caused disease in mice, suggesting that they were apathogenic. Garbutt and colleagues then inoculated all three groups of mice with a lethal dose of mouse-adapted EBOV twenty-eight days after their initial inoculation with VSV. All mice developed disease and succumbed-except those that had been originally inoculated with VSV-EBOV. This was the first indication that the VSV-based vaccine platform could be used to elicit an immune response against a heterologous glycoprotein that, in turn, could protect animals from disease. 
Figure 1: Vesicular stomatitis virus vaccine platform

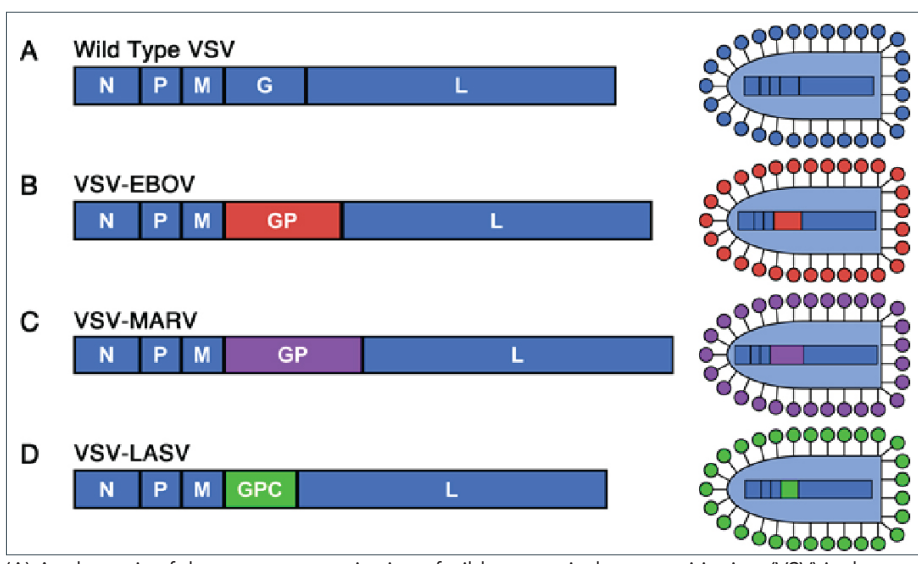

(A) A schematic of the genome organization of wild type vesicular stomatitis virus (VSV) is shown on the left, with the open reading frames for the nucleoprotein $(N)$, the phosphoprotein $(P)$, the matrix protein $(\mathrm{M})$, the glycoprotein $(\mathrm{G})$ and the RNA-dependent RNA polymerase large protein $(\mathrm{L})$ indicated. A schematic of the VSV virion is shown on the right, with the genome encased within the bullet-shaped virion studded with $G$. (B) A schematic of the genome organization of VSV-EBOV is shown on the left, with VSV G replaced with the Ebola virus (EBOV) glycoprotein GP) open reading frame. A schematic of the VSV virion is shown on the right, with the gen GP) open rache encased within the bullet-shaped organization of VSV-Marburg virus (MARV) is shown on the left, with VSV G replaced with the MARV glycoprotein (GP) open reading frame. A schematic of the VSV virion is shown on the right, with the genome encased within the bullet-shaped virion studded with GP. (D) A schematic of the genome organization of VSV-LASV is shown on the left, with VSV G replaced with the Lassa virus (LASV) glycoprotein precursor (GPC) open reading frame. A schematic of the VSV virion is shown on the right, with the genome encased within the bullet-shaped virion studded with GPC

Shortly after the efficacy of the VSV-EBOV vaccine was demonstrated in mice (31), the same group published the first characterization of the VSV-LASV vaccine in nonhuman primates (32). Cynomolgus macaques were vaccinated intramuscularly with a single dose of VSV-LASV. The animals neither developed signs of disease nor shed vaccine virus, underscoring the safety of this vector. Twenty-eight days later, the animals were challenged with LASV. All the vaccinated animals survived, and none developed signs of Lassa fever. The vaccine appeared to induce both humoral and cellular immune responses, and there were no marked differences in the blood chemistry or hematology of the animals before and after LASV challenge. In contrast, two control animals vaccinated with VSV-EBOV developed clinical manifestations consistent with Lassa fever and succumbed to disease, with no detectable LASV-specific immune response. This study offered a preliminary-but extremely promisingdemonstration of the efficacy of the VSV-LASV vaccine; however, it would be nearly a decade before follow-up experiments were performed.

In 2013, EBOV emerged for the first time in Western Africa and sparked an unprecedented outbreak. The EBOV was now present, and possibly endemic, in the same geographical location as LASV, and concerns were raised that a single vaccine platform may be ineffective if used to vaccinate separately against multiple pathogens. To address this concern, Marzi et al. (33) vaccinated a group of three cynomolgus macaques with a single dose of VSV-LASV and challenged the animals twenty-eight days later with LASV. None of the animals exhibited any signs of disease and the absence of a strong antibody response suggested that vaccination induced sterile or near-sterile immunity. Sixty days later, the same three animals were vaccinated with a single dose of VSV-EBOV and were subsequently challenged with EBOV. Despite high titers of anti-VSV antibodies at the time of the second vaccination, all three animals were completely protected from EBOV infection and exhibited a robust immune response. Thus, pre-existing immunity to the VSV backbone did not compromise the efficacy of the vaccine, indicating that multiple VSV-based vaccines can likely be used in a single population.

There remained the critical question of whether a single VSV-LASV vaccination could prevent disease caused by multiple LASV isolates, since LASV exhibits a high degree of genetic diversity among geographically separated viruses (34). Safronetz et al. (35) addressed this question first in a guinea pig model of LASV infection, demonstrating that VSV-LASV completely protected animals from three heterologous LASV isolates: Z-132 (from Liberia), Soromba-R (from Mali) and Pinneo (from Nigeria). Likewise, vaccination with VSV-LASV protected cynomolgus macaques from lethal challenge with LASV strain Z-132. These results indicate that a single vaccination may offer universal protection against all strains of LASV and may be deployable over the entire LASV endemic range, which comprises at least nine countries and hundreds of millions of people.

\section{Pre-clinical development of vesicular stomatitis virus-based vaccines}

Pre-clinical testing of VSV-LASV in various animal models, including nonhuman primates, has demonstrated that this vaccine is safe and effective at eliciting a broadly protective immune response against LASV, in spite of pre-existing immunity to VSV. Despite the promise of this vaccine, clinical development of VSV-LASV is still pending. Nevertheless, the VSV platform has been extensively tested via the VSV-EBOV vaccine, which has undergone rigorous pre-clinical and clinical development $(36,37)$, including phase III human clinical trials where it demonstrated $100 \%$ efficacy (30). Similarly, VSV-MARV has undergone extensive pre-clinical development (38), and VSV-based vaccines have also been developed for other filoviruses, including Sudan and Bundibugyo virus $(39,40)$, all of which show remarkable prophylactic efficacy (36-38). Indeed, work with VSV-based filovirus vaccines over the last several years has contributed significantly to our understanding of filovirus disease and the VSV vaccine platform.

Research on the VSV-EBOV vaccine has identified that the formation of antibodies is a critical correlate of protection (41). Studies with VSV-MARV have indicated that vaccine-induced immunity is durable, remaining effective for at least 14 months in the nonhuman primate model (42). Moreover, the VSV-EBOV vaccine-and, by extension, the VSV $\triangle G$ backbonehas been demonstrated to be safe in immunocompromised animals (i.e., nonhuman primates infected with simian-human immunodeficiency virus) and livestock animals $(43,44)$. Owing to the poor cross-species protection offered by the monovalent VSV-based vaccines, trivalent and blended monovalent single-dose vaccines have also been developed and demonstrate $100 \%$ efficacy, suggesting that the VSV platform can be manipulated and optimized to protect against multiple viruses at once $(22,39)$. Finally, phase I, II and III clinical trials have affirmed the overall safety, tolerability, and immunogenicity of the VSV-EBOV vaccine, even at high doses $(25,30,45-49)$. Of note, rare adverse effects have been observed (30), with one phase I clinical trial recording a relatively high incidence of vaccine-induced arthritis, dermatitis, and vasculitis $(45,46)$. 


\section{Assessing the risk to livestock}

The use of a live, VSV-based vaccine impacts not only the humans who receive it, but also potentially the animals that come into contact with vaccinated humans. Because VSV is a reportable livestock illness, the use of a VSV-based vaccine carries with it the risk that the VSV vector may impact livestock animals, potentially precipitating an agricultural and regulatory crisis. To address this concern, de Wit et al. (44) inoculated pigs with high doses of VSV-EBOV or wild type VSV and monitored the animals for signs of infection and disease. Remarkably, regardless of the virus used for infection, virus replication was detected in a minority of animals, viremia was absent, virus shedding was minimal, and no animal displayed any overt signs of infection. Given the absence of disease in the pigs following direct inoculation of virus, it is unlikely that a vaccinated human could transmit virus to a pig in a way that would trigger a productive infection with overt signs of disease. Moreover, even in the event of such a transmission, the vaccine virus is unlikely to be maintained in the animal population. This study confirms the safety of VSV-based vaccines and suggests that the potential impact of these vaccines on livestock health is minimal.

\section{Alternatives to vesicular stomatitis virus-based Lassa fever vaccine}

In an effort to identify a safe and effective vaccine against LASV, a number of different platforms have been developed over the last several decades $(50,51)$ (Table 1). Replication-competent vaccinia virus-vectored vaccines encoding the LASV nucleoprotein and/ or glycoprotein were among the first platforms to be devised and have demonstrated reasonable efficacy in guinea pigs and nonhuman primates (52-56). Due to the immunosuppressive nature of vaccinia virus, further development of this vaccine platform was abandoned out of safety concerns, particularly in immunocompromised individuals (51). The yellow fever virus 17D (YF17D) backbone, which encodes the LASV glycoprotein or glycoprotein subunits, has also been developed as a LASV vaccine, although its immunogenicity is poor and it lacks efficacy in nonhuman primates $(50,57,58)$. Likewise, inactivated LASV failed to protect nonhuman primates from fatal Lassa fever (59). Alphavirus replicons, which are self-replicating RNA molecules expressing foreign antigens instead of alphavirus structural proteins and packaged in virus-like particles, have shown promising results as LASV vaccines, including the ability to promote CD8+ T-cell responses and confer complete protection in guinea pigs, but they await additional characterization (60-62). Notably, a DNA-based LASV vaccine offered complete protection from LASV in guinea pigs and nonhuman primates but required multiple administrations, which may not be practical in LASV-endemic regions (63-65).

In addition to VSV-LASV, the most advanced LASV vaccine candidate is based on a reassortant between LASV and the reportedly non-pathogenic Mopeia virus (MOPV) $(50,51)$. Clone ML29 possesses genetic material from both MOPV and LASVincluding the nucleoprotein and glycoprotein genes from the latter-and includes several additional point mutations that are thought to further attenuate the virus $(66,70,71)$. Vaccination with ML29 has been shown to be safe and to elicit a potent and protective immune response against LASV. Indeed, it offers complete protection in guinea pigs and nonhuman primates, remains efficacious when administered up to two
Table 1: Lassa virus vaccine candidates and their evaluation in animal models

\begin{tabular}{|c|c|c|c|c|}
\hline Platform & $\begin{array}{c}\text { LASV } \\
\text { antigen }\end{array}$ & $\begin{array}{c}\text { Guinea pig } \\
\text { efficacy }\end{array}$ & $\begin{array}{c}\text { Nonhuman } \\
\text { primate } \\
\text { efficacy }\end{array}$ & Reference \\
\hline \multicolumn{5}{|c|}{ Replication-competent vaccines } \\
\hline $\begin{array}{l}\text { Vaccinia virus } \\
\text { (Lister) }\end{array}$ & $\mathrm{N}$ & $100 \%$ survival & - & 55 \\
\hline \multirow{10}{*}{$\begin{array}{l}\text { Vaccinia virus } \\
\text { (NYBH) }\end{array}$} & \multirow[t]{4}{*}{ GPC } & $100 \%$ survival & - & 54 \\
\hline & & - & $\begin{array}{l}100 \% \\
\text { survival } \\
\text { (rhesus) }\end{array}$ & 53 \\
\hline & & $79 \%$ survival & - & 52 \\
\hline & & - & $\begin{array}{l}67 \% \text { survival } \\
\text { (cynos) } \\
100 \% \\
\text { survival } \\
\text { (rhesus) }\end{array}$ & 51 \\
\hline & GP1 & - & $\begin{array}{l}0 \% \text { survival } \\
\text { (cynos) }\end{array}$ & 51 \\
\hline & GP2 & - & $\begin{array}{l}0 \% \text { survival } \\
\text { (cynos) }\end{array}$ & 51 \\
\hline & $\begin{array}{l}\text { GP1 \& GP2 } \\
\text { (separate } \\
\text { vector) }\end{array}$ & - & $\begin{array}{l}100 \% \\
\text { survival } \\
\text { (rhesus) }\end{array}$ & 51 \\
\hline & $\mathrm{N}$ & $94 \%$ survival & $\begin{array}{l}0 \% \text { survival } \\
\text { (cynos) } \\
43 \% \text { survival } \\
\text { (rhesus) }\end{array}$ & 51,52 \\
\hline & $\begin{array}{l}\text { N \& GPC } \\
\text { (separate } \\
\text { vectors) }\end{array}$ & $58 \%$ survival & $\begin{array}{l}75 \% \text { survival } \\
\text { (cynos) } \\
100 \% \\
\text { survival } \\
\text { (rhesus) }\end{array}$ & 51,52 \\
\hline & $\begin{array}{l}\text { N \& GPC } \\
\text { (same vector) }\end{array}$ & - & $\begin{array}{l}100 \% \\
\text { survival } \\
\text { (rhesus) }\end{array}$ & 51 \\
\hline \multirow[t]{2}{*}{ VSV } & GPC & $100 \%$ survival & $\begin{array}{l}100 \% \\
\text { survival } \\
\text { (cynos) }\end{array}$ & $31,32,34$ \\
\hline & $\mathrm{N}$ & $67 \%$ survival & - & 34 \\
\hline ML29 & $\begin{array}{l}\text { N \& GPC } \\
\text { (same vector) }\end{array}$ & $100 \%$ survival & $\begin{array}{l}100 \% \\
\text { survival } \\
\text { (marmosets) }\end{array}$ & $66,67,68$ \\
\hline \multirow[t]{2}{*}{ YFV17D } & GPC & $80 \%$ survival & $\begin{array}{l}0 \% \text { survival } \\
\text { (marmosets) }\end{array}$ & 57,69 \\
\hline & $\begin{array}{l}\text { GP1 \& GP2 } \\
\text { (same vector) }\end{array}$ & $83 \%$ survival & - & 56 \\
\hline \multicolumn{5}{|l|}{ Other vaccines } \\
\hline $\begin{array}{l}\text { Inactivated } \\
\text { LASV }\end{array}$ & $\begin{array}{l}\text { Inactivated } \\
\text { LASV }\end{array}$ & - & $\begin{array}{l}0 \% \text { survival } \\
\text { (rhesus) }\end{array}$ & 58 \\
\hline \multirow{4}{*}{$\begin{array}{l}\text { Alphavirus } \\
\text { replicon }\end{array}$} & $\mathrm{N}$ & $100 \%$ survival & - & 60 \\
\hline & GPC & $100 \%$ survival & - & 60 \\
\hline & $\begin{array}{l}\text { N \& GPC } \\
\text { (separate } \\
\text { vector) }\end{array}$ & $100 \%$ survival & - & 60 \\
\hline & $\begin{array}{l}\text { GPC \& EBOV } \\
\text { GP } \\
\text { (same vector) }\end{array}$ & $100 \%$ survival & - & 60 \\
\hline $\begin{array}{l}\text { DNA/ } \\
\text { electroporation }\end{array}$ & GPC & $\begin{array}{l}83-100 \% \\
\text { survival }\end{array}$ & $\begin{array}{l}100 \% \\
\text { survival }\end{array}$ & $62-64$ \\
\hline
\end{tabular}

Abbreviations: EBOV, Ebola virus; GP, glycoprotein; GP1, glycoprotein 1; GP2, glycoprotein 2 GPC, glycoprotein precursor; LASV, Lassa virus; N, nucleoprotein; NYBH, New York Board of Health; VSV, vesicular stomatitis virus; YF17D, Yellow fever 17D; "-", not done 
days post-infection, is safe in immunocompromised animals and appears to be genetically stable with no propensity to undergo reassortment with pathogenic $\operatorname{LASV}(67,68,70,72,73)$; however, until recently, ML29 was classified by the US Centers for Disease Control as a Risk Group 3 pathogen, indicating that further safety validation may be warranted.

\section{Discussion}

Lassa virus causes hundreds of thousands of infections each year and results in thousands of deaths (5). Despite the clear threat that LASV poses to public health, the virus, as well as the disease that it causes, remain under studied. Largely for this reason, the World Health Organization has listed LASV as a priority disease in their Research and Development Blueprint that is designed to improve global research coordination, accelerate development of countermeasures and provide a framework for outbreak response (74). This Blueprint aims to develop a five-year accelerated research plan to advance LASV vaccines into phase III clinical trials. Moreover, the Coalition for Epidemic Preparedness and Innovations has committed to funding the advanced development of select candidate LASV vaccines, although exactly which vaccine platforms will be pursued has yet to be announced.

Although significant progress has been made towards the goal of developing a safe and effective LASV vaccine, further research is required. Many important questions concerning the use and efficacy of the VSV-LASV vaccine remain, particularly the question of the mechanism(s) of action. Activated CD8+ T-cells were noted in a majority of nonhuman primates vaccinated with VSV-LASV (32), suggesting that the cellular immune response plays an important role in protection. Indeed, control of Lassa fever in nonhuman primates has been correlated with the circulation of activated CD4+ and CD8+ T-cells (75), and nonfatal Lassa fever in humans has been shown to be associated with high levels of T-cell-attracting chemokines (76-78). Conversely, the humoral response to LASV infection does not appear to play a significant role in recovery from infection $(75,79-81)$, and neutralizing antibodies seem to be poorly elicited $(32,69,75,78)$. In contrast to the VSV-EBOV vaccine, in which antibodies play a critical role in protection (41), the humoral response appears to play little role in the protection elicited by VSV-LASV vaccine, although more work is required in this area. Time-to-immunity, immune durability and post-exposure therapeutic efficacy of the vaccine also remain to be investigated. Finally, whether the VSV-LASV vaccine, like the EBOV vaccine, is safe and efficacious in immunocompromised individuals is of particular concern should the vaccine ever be deployed in LASV endemic regions, where HIV-1 seropositivity is high. Despite the work that remains to be done, VSV-LASV is still among the most promising of the LASV vaccines currently in development.

\section{Conclusion}

The VSV-LASV vaccine is ready for further clinical development. A panel of experts surveyed by Science magazine has already identified it as one of two LASV vaccine candidates with the most potential (82). Not only does the VSV-LASV vaccine offer complete protection against a number of different LASV strains, but the platform upon which it is built, VSV $\Delta \mathrm{G}$, has also been extensively characterized. Although safety concerns have been raised regarding the VSV platform, particularly in the context of the EBOV vaccine, the majority of available clinical trial data suggests that VSV-EBOV is both safe and effective. Likewise, the vector appears unlikely to pose a threat to livestock animals.

The next step in the development of the VSV-LASV vaccine is phase I human clinical trials to assess vaccine safety and dosage. As LASV continues to exact its perennial toll upon Western Africa, including the outbreak currently affecting Nigeria, the political and social will to develop a safe and effective vaccine against this disease has never been stronger. The VSV-LASV seems well positioned to be part of the solution to reduce the threat that LASV poses to the world.

\section{Authors' statement}

LB - Writing - original draft; writing - reviewing and editing DRS - Writing - original draft; writing - reviewing and editing $X Q$ - Writing - reviewing and editing; supervision DS - Initial conception; writing - reviewing and editing; supervision LB and DRS contributed equally to this article.

\section{Conflict of interest}

The authors declare no conflict of interest.

\section{Acknowledgments}

The authors wish to thank Jonathan Audet for his expert technical assistance with the French manuscript.

\section{Funding}

This work was supported by the Public Health Agency of Canada.

\section{References}

1. Tam T. Fifteen years post-SARS: key milestones in Canada's public health emergency response. Can Commun Dis Rep 2018;44(5):98101. https://www.canada.ca/en/public-health/services/ reports-publications/canada-communicable-disease-reportccdr/monthly-issue/2018-44/issue-5-may-3-2018/article1-post-sars-key-milestones.html

2. World Health Organization. Ebola Situation Report - 30 March 2016. WHO: 2016. http://apps.who.int/ebola/current-situation/ ebola-situation-report-30-march-2016

3. World Health Organization. Health worker Ebola infections in Guinea, Liberia and Sierra Leone. Preliminary Report. WHO: 2015. www.who.int/csr/resources/publications/ebola/ health-worker-infections/en/

4. Buchmeier MJ, de la Torre J, Peters CJ. Arenaviridae: The Viruses and Their Replication. In: Knipe DM, Howley PM, editors. Fields Virology. $5^{\text {th }}$ ed. Philadelphia, PA: Lippincott Williams \& Wilkins; 2007. 
5. McCormick JB, Webb PA, Krebs JW, Johnson KM, Smith ES. A prospective study of the epidemiology and ecology of Lassa fever. J Infect Dis 1987 Mar;155(3):437-44. http://dx.doi.org/10.1093/ infdis/155.3.437. PubMed (https://www.ncbi.nlm.nih.gov/ pubmed/3805771)

6. Falzarano D, Feldmann $\mathrm{H}$. Vaccines for viral hemorrhagic fevers-progress and shortcomings. Curr Opin Virol 2013 Jun;3(3):343-51. http://dx.doi.org/10.1016/j.coviro.2013.04.007. PubMed (https://www.ncbi.nlm.nih.gov/pubmed/23773330)

7. Ogbu O, Ajuluchukwu E, Uneke CJ. Lassa fever in West African sub-region: an overview. J Vector Borne Dis 2007 Mar;44(1):1-11. PubMed (www.ncbi.nlm.nih.gov/pubmed/17378212)

8. Bausch DG, Demby AH, Coulibaly M, Kanu J, Goba A, Bah A, Condé N, Wurtzel HL, Cavallaro KF, Lloyd E, Baldet FB, Cissé SD, Fofona D, Savané IK, Tolno RT, Mahy B, Wagoner KD, Ksiazek TG, Peters CJ, Rollin PE. Lassa fever in Guinea: I. Epidemiology of human disease and clinical observations. Vector Borne Zoonotic Dis 2001;1(4):26981. http://dx.doi.org/10.1089/15303660160025903. PubMed (https://www.ncbi.nlm.nih.gov/pubmed/12653127)

9. Frame JD. Clinical features of Lassa fever in Liberia. Rev Infect Dis 1989 May-Jun;11(Suppl 4):S783-9. http://dx.doi.org/10.1093/ clinids/11.Supplement_4.S783. PubMed (www.ncbi.nlm.nih.gov/ pubmed/2749109)

10. McCormick JB, King IJ, Webb PA, Johnson KM, O'Sullivan R, Smith ES, Trippel S, Tong TC. A case-control study of the clinical diagnosis and course of Lassa fever. J Infect Dis 1987 Mar;155(3):445-55. http://dx.doi.org/10.1093/infdis/155.3.445. PubMed (www. ncbi.nlm.nih.gov/pubmed/3805772)

11. Nigeria Centre for Disease Control. 2018 Lassa Fever Outbreak in Nigeria (for Week 15; April 15, 2018). World Health Organization; 2018. www.ncdc.gov.ng/diseases/sitreps

12. Lyles DS, Rupprecht CE. Rhabdoviridae. In: Knipe DM, Howley PM, editors. Fields Virology. 5th ed. Philadelphia, PA: Lippincott Williams \& Wilkins; 2007.

13. Amarasinghe GK, Bào $Y$, Basler $C F$, Bavari $S$, Beer $M$, Bejerman $\mathrm{N}$, Blasdell KR, Bochnowski A, Briese T, Bukreyev A, Calisher CH, Chandran K, Collins PL, Dietzgen RG, Dolnik O, Dürrwald R, Dye JM, Easton AJ, Ebihara H, Fang Q, Formenty P, Fouchier RAM, Ghedin E, Harding RM, Hewson R, Higgins CM, Hong J, Horie M, James $A P$, Jiang $D$, Kobinger GP, Kondo $H$, Kurath G, Lamb RA, Lee B, Leroy EM, Li M, Maisner A, Mühlberger E, Netesov SV, Nowotny N, Patterson JL, Payne SL, Paweska JT, Pearson MN, Randall RE, Revill PA, Rima BK, Rota P, Rubbenstroth D, Schwemmle M, Smither SJ, Song Q, Stone DM, Takada A, Terregino C, Tesh RB, Tomonaga K, Tordo N, Towner JS, Vasilakis N, Volchkov VE, Wahl-Jensen V, Walker PJ, Wang B, Wang D, Wang F, Wang LF, Werren JH, Whitfield AE, Yan Z, Ye G, Kuhn JH. Taxonomy of the order Mononegavirales: update 2017. Arch Virol 2017 Aug;162(8):2493-504. http://dx.doi org/10.1007/s00705-017-3311-7. PubMed (https://www.ncbi. nlm.nih.gov/pubmed/28389807)

14. Letchworth GJ, Rodriguez LL, Del cbarrera J. Vesicular stomatitis. Vet J 1999 May;157(3):239-60. http://dx.doi.org/10.1053/ tvjl.1998.0303. PubMed (https://www.ncbi.nlm.nih.gov/ pubmed/10328837)

15. Brandly CA, Hanson RP. Epizootiology of vesicular stomatitis. Am J Public Health Nations Health 1957 Feb;47(2):205-9. http://dx.doi. org/10.2105/AJPH.47.2.205. PubMed (https://www.ncbi.nlm. nih.gov/pubmed/13394773)

16. Johnson KM, Vogel JE, Peralta PH. Clinical and serological response to laboratory-acquired human infection by Indiana type vesicular stomatitis virus (VSV). Am J Trop Med Hyg 1966 Mar;15(2):244-6. http://dx.doi.org/10.4269/ajtmh.1966.15.244. PubMed (https://www.ncbi.nlm.nih.gov/pubmed/4286381)

17. Brody JA, Fischer GF, Peralta PH. Vesicular stomatitis virus in Panama. Human serologic patterns in a cattle raising area. Am J
Epidemiol 1967 Jul;86(1):158-61. http://dx.doi.org/10.1093/ oxfordjournals.aje.a120721. PubMed (https://www.ncbi.nlm.nih. gov/pubmed/4378113)

18. Whelan SP, Ball LA, Barr JN, Wertz GT. Efficient recovery of infectious vesicular stomatitis virus entirely from cDNA clones. Proc Natl Acad Sci USA 1995 Aug;92(18):8388-92. http://dx.doi.org/10.1073/ pnas.92.18.8388. PubMed (https://www.ncbi.nlm.nih.gov/ pubmed/7667300)

19. Lawson ND, Stillman EA, Whitt MA, Rose JK. Recombinant vesicular stomatitis viruses from DNA. Proc Natl Acad Sci USA 1995 May;92(10):4477-81. http://dx.doi.org/10.1073/ pnas.92.10.4477. PubMed (https://www.ncbi.nlm.nih.gov/ pubmed/7753828)

20. Roberts A, Kretzschmar E, Perkins AS, Forman J, Price R, Buonocore L, Kawaoka Y, Rose JK. Vaccination with a recombinant vesicular stomatitis virus expressing an influenza virus hemagglutinin provides complete protection from influenza virus challenge. J Virol 1998 Jun;72(6):4704-11. PubMed (https://www.ncbi.nlm.nih.gov/ pubmed/9573234)

21. Haglund K, Forman J, Kräusslich HG, Rose JK. Expression of human immunodeficiency virus type $1 \mathrm{Gag}$ protein precursor and envelope proteins from a vesicular stomatitis virus recombinant: high-level production of virus-like particles containing HIV envelope. Virology 2000 Mar;268(1):112-21. http://dx.doi.org/10.1006/viro.1999.0120. PubMed (https://www.ncbi.nlm.nih.gov/pubmed/10683333)

22. Mire CE, Geisbert JB, Versteeg KM, Mamaeva N, Agans KN, Geisbert TW, Connor JH. A Single-Vector, Single-Injection Trivalent Filovirus Vaccine: Proof of Concept Study in Outbred Guinea Pigs. J Infect Dis 2015 Oct;212(Suppl 2):S384-8. http://dx.doi. org/10.1093/infdis/jiv126. PubMed (https://www.ncbi.nlm.nih. gov/pubmed/25957964)

23. Johnson JE, Schnell MJ, Buonocore L, Rose JK. Specific targeting to CD4+ cells of recombinant vesicular stomatitis viruses encoding human immunodeficiency virus envelope proteins. J Virol 1997 Jul;71(7):5060-8. PubMed (https://www.ncbi.nlm.nih.gov/ pubmed/9188571)

24. Kretzschmar E, Buonocore L, Schnell MJ, Rose JK. High-efficiency incorporation of functional influenza virus glycoproteins into recombinant vesicular stomatitis viruses. J Virol 1997 Aug;71(8):5982-9. PubMed (https://www.ncbi.nlm.nih.gov/ pubmed/9223488)

25. Regules JA, Beigel JH, Paolino KM, Voell J, Castellano AR, Hu Z, Muñoz P, Moon JE, Ruck RC, Bennett JW, Twomey PS, Gutiérrez RL, Remich SA, Hack HR, Wisniewski ML, Josleyn MD, Kwilas SA, Van Deusen N, Mbaya OT, Zhou Y, Stanley DA, Jing W, Smith KS, Shi M, Ledgerwood JE, Graham BS, Sullivan NJ, Jagodzinski LL, Peel SA, Alimonti JB, Hooper JW, Silvera PM, Martin BK, Monath TP, Ramsey WJ, Link CJ, Lane HC, Michael NL, Davey RT Jr, Thomas SJ; rVSV $\triangle$ G-ZEBOV-GP Study Group. A Recombinant Vesicular Stomatitis Virus Ebola Vaccine. N Engl J Med 2017 Jan;376(4):330 41. http://dx.doi.org/10.1056/NEJMoa1414216. PubMed (https://www.ncbi.nlm.nih.gov/pubmed/25830322)

26. Freer G, Burkhart C, Ciernik I, Bachmann MF, Hengartner $H$, Zinkernagel RM. Vesicular stomatitis virus Indiana glycoprotein as a T-cell-dependent and -independent antigen. J Virol 1994 Jun;68(6):3650-5.

27. Kündig TM, Castelmur I, Bachmann MF, Abraham D, Binder D, Hengartner $\mathrm{H}$, Zinkernagel RM. Fewer protective cytotoxic T-cell epitopes than T-helper-cell epitopes on vesicular stomatitis virus [abstract]. J Virol 1993 Jun;67(6):3680-3. PubMed (https://www. ncbi.nlm.nih.gov/pubmed/7684471)

28. Zinkernagel RM, Adler B, Holland JJ. Cell-mediated immunity to vesicular stomatitis virus infections in mice. Exp Cell Biol 1978;46(12):53-70. PubMed (https://www.ncbi.nlm.nih.gov/pubmed/202522)

29. Fuchs JD, Frank I, Elizaga ML, Allen M, Frahm N, Kochar N, Li S, Edupuganti S, Kalams SA, Tomaras GD, Sheets R, Pensiero M, 
Tremblay MA, Higgins TJ, Latham T, Egan MA, Clarke DK, Eldridge JH, HVTN 090 Study Group and the National Institutes of Allergy and Infectious Diseases HIV Vaccine Trials Network, Mulligan M, Rouphael N, Estep S, Rybczyk K, Dunbar D, Buchbinder S, Wagner T, Isbell R, Chinnell V, Bae J, Escamilla G, Tseng J, Fair R, Ramirez S, Broder G, Briesemeister L, Ferrara A. First-in-Human Evaluation of the Safety and Immunogenicity of a Recombinant Vesicular Stomatitis Virus Human Immunodeficiency Virus-1 gag Vaccine (HVTN 090). Open Forum Infect Dis 2015 Jun;2(3):ofv082. http:// dx.doi.org/10.1093/ofid/ofv082. PubMed (https://www.ncbi. nlm.nih.gov/pubmed/26199949)

30. Henao-Restrepo AM, Camacho A, Longini IM, Watson $\mathrm{CH}$, Edmunds WJ, Egger M, Carroll MW, Dean NE, Diatta I, Doumbia M, Draguez B, Duraffour S, Enwere G, Grais R, Gunther S, Gsell PS, Hossmann S, Watle SV, Kondé MK, Kéïa S, Kone S, Kuisma E, Levine MM, Mandal S, Mauget T, Norheim G, Riveros X, Soumah A, Trelle S, Vicari AS, Røttingen JA, Kieny MP. Efficacy and effectiveness of an rVSV-vectored vaccine in preventing Ebola virus disease: final results from the Guinea ring vaccination, open-label, cluster-randomised trial (Ebola Ça Suffit!). Lancet 2017 Feb;389(10068):505-18. http:// dx.doi.org/10.1016/S0140-6736(16)32621-6. PubMed (https:// www.ncbi.nlm.nih.gov/pubmed/28017403)

31. Garbutt M, Liebscher R, Wahl-Jensen V, Jones $S$, Möller P, Wagner R, Volchkov V, Klenk HD, Feldmann H, Ströher U. Properties of replication-competent vesicular stomatitis virus vectors expressing glycoproteins of filoviruses and arenaviruses. J Virol 2004 May;78(10):5458-65. http://dx.doi.org/10.1128/ JVI.78.10.5458-5465.2004. PubMed (https://www.ncbi.nlm.nih. gov/pubmed/15113924)

32. Geisbert TW, Jones S, Fritz EA, Shurtleff AC, Geisbert JB, Liebscher R, Grolla A, Ströher U, Fernando L, Daddario KM, Guttieri MC, Mothé BR, Larsen T, Hensley LE, Jahrling PB, Feldmann H. Development of a new vaccine for the prevention of Lassa fever. PLoS Med 2005 Jun;2(6):e183. http://dx.doi.org/10.1371/ journal.pmed.0020183. PubMed (https://www.ncbi.nlm.nih.gov/ pubmed/15971954)

33. Marzi A, Feldmann F, Geisbert TW, Feldmann H, Safronetz D. Vesicular stomatitis virus-based vaccines against Lassa and Ebola viruses. Emerg Infect Dis 2015 Feb;21(2):305-7. http://dx.doi. org/10.3201/eid2102.141649. PubMed (https://www.ncbi.nlm. nih.gov/pubmed/25625358)

34. Bowen MD, Rollin PE, Ksiazek TG, Hustad HL, Bausch DG, Demby AH, Bajani MD, Peters CJ, Nichol ST. Genetic diversity among Lassa virus strains. J Virol 2000 Aug;74(15):6992-7004. http://dx.doi. org/10.1128/JVI.74.15.6992-7004.2000. PubMed (https:// www.ncbi.nlm.nih.gov/pubmed/10888638)

35. Safronetz D, Mire C, Rosenke K, Feldmann F, Haddock E, Geisbert $\mathrm{T}$, Feldmann $\mathrm{H}$. A recombinant vesicular stomatitis virus-based Lassa fever vaccine protects guinea pigs and macaques against challenge with geographically and genetically distinct Lassa viruses. PLoS Negl Trop Dis 2015 Apr;9(4):e0003736. http://dx.doi.org/10.1371/ journal.pntd.0003736. PubMed (https://www.ncbi.nlm.nih.gov/ pubmed/25884628)

36. Wong G, Mendoza EJ, Plummer FA, Gao GF, Kobinger GP, Qiu X. From bench to almost bedside: the long road to a licensed Ebola virus vaccine. Expert Opin Biol Ther 2018 Feb;18(2):159-73. http:// dx.doi.org/10.1080/14712598.2018.1404572. PubMed (https://www.ncbi.nlm.nih.gov/pubmed/29148858)

37. Mire CE, Geisbert TW, Feldmann H, Marzi A. Ebola virus vaccines - reality or fiction? Expert Rev Vaccines 2016 Nov; 15(11):1421-30. http://dx.doi.org/10.1080/14760584.2016.1178068. PubMed (https://www.ncbi.nlm.nih.gov/pubmed/27078187)

38. Reynolds P, Marzi A. Ebola and Marburg virus vaccines. Virus Genes 2017 Aug;53(4):501-15. http://dx.doi.org/10.1007/ s11262-017-1455-x. PubMed (https://www.ncbi.nlm.nih.gov/ pubmed/28447193)
39. Geisbert TW, Geisbert JB, Leung A, Daddario-DiCaprio KM, Hensley LE, Grolla A, Feldmann H. Single-injection vaccine protects nonhuman primates against infection with marburg virus and three species of ebola virus. J Virol 2009 Jul;83(14):7296-304. http:// dx.doi.org/10.1128/JVI.00561-09. PubMed (https://www.ncbi. nlm.nih.gov/pubmed/19386702)

40. Mire CE, Geisbert JB, Marzi A, Agans KN, Feldmann H, Geisbert TW. Vesicular stomatitis virus-based vaccines protect nonhuman primates against Bundibugyo ebolavirus. PLoS Negl Trop Dis 2013 Dec;7(12):e2600. http://dx.doi.org/10.1371/journal. pntd.0002600. PubMed (https://www.ncbi.nlm.nih.gov/ pubmed/24367715)

41. Marzi A, Engelmann F, Feldmann F, Haberthur K, Shupert WL, Brining D, Scott DP, Geisbert TW, Kawaoka Y, Katze MG, Feldmann $\mathrm{H}$, Messaoudi I. Antibodies are necessary for rVSV/ZEBOV-GPmediated protection against lethal Ebola virus challenge in nonhuman primates. Proc Natl Acad Sci USA 2013 Jan;110(5):18938. http://dx.doi.org/10.1073/pnas.1209591110. PubMed (https://www.ncbi.nlm.nih.gov/pubmed/23319647)

42. Mire CE, Geisbert JB, Agans KN, Satterfield BA, Versteeg KM, Fritz EA, Feldmann H, Hensley LE, Geisbert TW. Durability of a vesicular stomatitis virus-based marburg virus vaccine in nonhuman primates. PLoS One 2014 Apr;9(4):e94355. http://dx.doi.org/10.1371/ journal.pone.0094355. PubMed (https://www.ncbi.nlm.nih.gov/ pubmed/24759889)

43. Geisbert TW, Daddario-Dicaprio KM, Lewis MG, Geisbert JB, Grolla A, Leung A, Paragas J, Matthias L, Smith MA, Jones SM, Hensley $\mathrm{LE}$, Feldmann H, Jahrling PB. Vesicular stomatitis virus-based ebola vaccine is well-tolerated and protects immunocompromised nonhuman primates. PLoS Pathog 2008 Nov;4(11):e1000225. http:// dx.doi.org/10.1371/journal.ppat.1000225. PubMed (https:// www.ncbi.nlm.nih.gov/pubmed/19043556)

44. de Wit E, Marzi A, Bushmaker T, Brining D, Scott D, Richt JA, Geisbert TW, Feldmann H. Safety of recombinant VSV-Ebola virus vaccine vector in pigs. Emerg Infect Dis 2015 Apr;21(4):702-4. http://dx.doi.org/10.3201/eid2104.142012. PubMed (https:// www.ncbi.nlm.nih.gov/pmc/articles/PMC4378486/)

45. Huttner A, Dayer JA, Yerly S, Combescure C, Auderset F, Desmeules J, Eickmann M, Finckh A, Goncalves AR, Hooper JW, Kaya G, Krähling $\bigvee$, Kwilas S, Lemaître B, Matthey A, Silvera P, Becker S, Fast PE, Moorthy V, Kieny MP, Kaiser L, Siegrist CA; VSV-Ebola Consortium. The effect of dose on the safety and immunogenicity of the VSV Ebola candidate vaccine: a randomised double-blind, placebo-controlled phase 1/2 trial. Lancet Infect Dis 2015 Oct;15(10):1156-66. http://dx.doi.org/10.1016/S14733099(15)00154-1. PubMed (https://www.ncbi.nlm.nih.gov/ pubmed/26248510)

46. Agnandji ST, Huttner A, Zinser ME, Njuguna P, Dahlke C, Fernandes JF, Yerly S, Dayer JA, Kraehling V, Kasonta R, Adegnika AA, Altfeld $M$, Auderset F, Bache EB, Biedenkopf N, Borregaard S, Brosnahan JS, Burrow R, Combescure C, Desmeules J, Eickmann M, Fehling SK, Finckh A, Goncalves AR, Grobusch MP, Hooper J, Jambrecina A, Kabwende AL, Kaya G, Kimani D, Lell B, Lemaître B, Lohse AW, Massinga-Loembe M, Matthey A, Mordmüller B, Nolting A, Ogwang C, Ramharter M, Schmidt-Chanasit J, Schmiedel S, Silvera P, Stahl FR, Staines HM, Strecker T, Stubbe HC, Tsofa B, Zaki S, Fast P, Moorthy V, Kaiser L, Krishna S, Becker S, Kieny MP, Bejon P, Kremsner PG, Addo MM, Siegrist CA. Phase 1 Trials of rVSV Ebola Vaccine in Africa and Europe. N Engl J Med 2016 Apr;374(17):164760. http://dx.doi.org/10.1056/NEJMoa1502924. PubMed (https://www.ncbi.nlm.nih.gov/pubmed/25830326)

47. ElSherif MS, Brown C, MacKinnon-Cameron D, Li L, Racine T, Alimonti J, Rudge TL, Sabourin C, Silvera P, Hooper JW, Kwilas SA, Kilgore N, Badorrek C, Ramsey WJ, Heppner DG, Kemp T, Monath TP, Nowak T, McNeil SA, Langley JM, Halperin SA; Canadian Immunization Research Network. Assessing the safety and immunogenicity of recombinant vesicular stomatitis virus Ebola vaccine in healthy adults: a randomized clinical trial. CMAJ 2017 
Jun;189(24):E819-27. http://dx.doi.org/10.1503/cmaj.170074. PubMed (https://www.ncbi.nlm.nih.gov/pubmed/28630358)

48. Agnandji ST, Fernandes JF, Bache EB, Obiang Mba RM, Brosnahan JS, Kabwende L, Pitzinger P, Staarink P, Massinga-Loembe M, Krähling V, Biedenkopf N, Fehling SK, Strecker T, Clark DJ, Staines HM, Hooper JW, Silvera P, Moorthy V, Kieny MP, Adegnika AA, Grobusch MP, Becker S, Ramharter M, Mordmüller B, Lell B; VEBCON Consortium, Krishna S, Kremsner PG. Safety and immunogenicity of $r V S V \triangle G-Z E B O V-G P$ Ebola vaccine in adults and children in Lambaréné, Gabon: A phase I randomised trial. PLoS Med 2017 Oct;14(10):e1002402. http://dx.doi.org/10.1371/ journal.pmed.1002402. PubMed (https://www.ncbi.nlm.nih.gov/ pubmed/28985239)

49. Halperin SA, Arribas JR, Rupp R, Andrews CP, Chu L, Das R, Simon JK, Onorato MT, Liu K, Martin J, Helmond FA; V920-012 Study Team. Six-Month Safety Data of Recombinant Vesicular Stomatitis Virus-Zaire Ebola Virus Envelope Glycoprotein Vaccine in a Phase 3 Double-Blind, Placebo-Controlled Randomized Study in Healthy Adults. J Infect Dis 2017 Jun;215(12):1789-98. http://dx.doi. org/10.1093/infdis/jix189. PubMed (https://www.ncbi.nlm.nih. gov/pubmed/28549145)

50. Lukashevich IS, Pushko P. Vaccine platforms to control Lassa fever. Expert Rev Vaccines 2016 Sep;15(9):1135-50. http://dx.doi.org/1 0.1080/14760584.2016.1184575. PubMed (https://www.ncbi. nlm.nih.gov/pubmed/27136941)

51. Lukashevich IS. Advanced vaccine candidates for Lassa fever. Viruses 2012 Oct;4(11):2514-57. http://dx.doi.org/10.3390/v4112514. PubMed (https://www.ncbi.nlm.nih.gov/pmc/articles/PMC3509661/)

52. Fisher-Hoch SP, Hutwagner L, Brown B, McCormick JB. Effective vaccine for lassa fever. J Virol 2000 Aug;74(15):6777-83. http:// dx.doi.org/10.1128/JVI.74.15.6777-6783.2000. PubMed (https://www.ncbi.nlm.nih.gov/pubmed/10888616)

53. Morrison HG, Bauer SP, Lange JV, Esposito JJ, McCormick JB, Auperin DD. Protection of guinea pigs from Lassa fever by vaccinia virus recombinants expressing the nucleoprotein or the envelope glycoproteins of Lassa virus. Virology 1989 Jul;171(1):179-88. http://dx.doi.org/10.1016/0042-6822(89)90525-4. PubMed (https://www.ncbi.nlm.nih.gov/pubmed/2741340)

54. Fisher-Hoch SP, McCormick JB, Auperin D, Brown BG, Castor M, Perez G, Ruo S, Conaty A, Brammer L, Bauer S. Protection of rhesus monkeys from fatal Lassa fever by vaccination with a recombinant vaccinia virus containing the Lassa virus glycoprotein gene. Proc Natl Acad Sci USA 1989 Jan;86(1):317-21. http://dx.doi.org/10.1073/ pnas.86.1.317. PubMed (https://www.ncbi.nlm.nih.gov/ pubmed/2911575)

55. Auperin DD, Esposito JJ, Lange JV, Bauer SP, Knight J, Sasso $\mathrm{DR}, \mathrm{McC}$ rmick JB. Construction of a recombinant vaccinia virus expressing the Lassa virus glycoprotein gene and protection of guinea pigs from a lethal Lassa virus infection. Virus Res 1988 Feb;9(2-3):233-48. http://dx.doi.org/10.1016/01681702(88)90033-0. PubMed (https://www.ncbi.nlm.nih.gov/ pubmed/3354260)

56. Clegg JC, Lloyd G. Vaccinia recombinant expressing Lassa-virus internal nucleocapsid protein protects guineapigs against Lassa fever. Lancet 1987 Jul;2(8552):186-8. http://dx.doi.org/10.1016/ S0140-6736(87)90767-7. PubMed (https://www.ncbi.nlm.nih. gov/pubmed/2885642)

57. Jiang X, Dalebout TJ, Bredenbeek PJ, Carrion R Jr, Brasky K, Patterson J, Goicochea M, Bryant J, Salvato MS, Lukashevich IS. Yellow fever 17D-vectored vaccines expressing Lassa virus GP1 and GP2 glycoproteins provide protection against fatal disease in guinea pigs. Vaccine $2011 \mathrm{Feb}$;29(6):1248-57. http://dx.doi. org/10.1016/j.vaccine.2010.11.079. PubMed (https://www.ncbi. nlm.nih.gov/pubmed/21145373)
58. Bredenbeek PJ, Molenkamp R, Spaan WJ, Deubel V, Marianneau P, Salvato MS, Moshkoff D, Zapata J, Tikhonov I, Patterson J, Carrion R, Ticer A, Brasky K, Lukashevich IS. A recombinant Yellow Fever 17D vaccine expressing Lassa virus glycoproteins. Virology 2006 Feb;345(2):299-304. http://dx.doi.org/10.1016/j. virol.2005.12.001. PubMed (https://www.ncbi.nlm.nih.gov/ pubmed/16412488)

59. McCormick JB, Mitchell SW, Kiley MP, Ruo S, Fisher-Hoch SP. Inactivated Lassa virus elicits a non protective immune response in rhesus monkeys. J Med Virol 1992 May;37(1):1-7. http://dx.doi. org/10.1002/jmv.1890370102. PubMed (https://www.ncbi.nlm. nih.gov/pubmed/1619397)

60. Wang M, Jokinen J, Tretyakova I, Pushko P, Lukashevich IS. Alphavirus vector-based replicon particles expressing multivalent cross-protective Lassa virus glycoproteins. Vaccine 2018 Jan;36(5):683-90. http://dx.doi.org/10.1016/j. vaccine.2017.12.046. PubMed (https://www.ncbi.nlm.nih.gov/ pubmed/29287681)

61. Pushko P, Geisbert J, Parker M, Jahrling P, Smith J. Individual and bivalent vaccines based on alphavirus replicons protect guinea pigs against infection with Lassa and Ebola viruses. J Virol 2001 Dec;75(23):11677-85. http://dx.doi.org/10.1128/ JVI.75.23.11677-11685.2001. PubMed (https://www.ncbi.nlm. nih.gov/pubmed/11689649)

62. Pushko P, Parker M, Ludwig GV, Davis NL, Johnston RE, Smith JF. Replicon-helper systems from attenuated Venezuelan equine encephalitis virus: expression of heterologous genes in vitro and immunization against heterologous pathogens in vivo. Virology 1997 Dec;239(2):389-401. http://dx.doi.org/10.1006/viro.1997.8878. PubMed (https://www.ncbi.nlm.nih.gov/pubmed/9434729)

63. Cashman KA, Broderick KE, Wilkinson ER, Shaia Cl, Bell TM, Shurtleff AC, Spik KW, Badger CV, Guttieri MC, Sardesai NY Schmaljohn CS. Enhanced Efficacy of a Codon-Optimized DNA Vaccine Encoding the Glycoprotein Precursor Gene of Lassa Virus in a Guinea Pig Disease Model When Delivered by Dermal Electroporation. Vaccines (Basel) 2013 Jul;1(3):262-77. http://dx.doi.org/10.3390/ vaccines1030262. PubMed (https://www.ncbi.nlm.nih.gov/ pubmed/26344112)

64. Cashman KA, Wilkinson ER, Shaia Cl, Facemire PR, Bell TM, Bearss JJ, Shamblin JD, Wollen SE, Broderick KE, Sardesai NY, Schmaljohn CS. A DNA vaccine delivered by dermal electroporation fully protects cynomolgus macaques against Lassa fever. Hum Vaccin Immunother 2017 Dec;13(12):2902-11. http://dx.doi.org/10.108 0/21645515.2017.1356500. PubMed (https://www.ncbi.nlm.nih. gov/pubmed/29045192)

65. Cashman KA, Wilkinson ER, Wollen SE, Shamblin JD, Zelko JM, Bearss JJ, Zeng X, Broderick KE, Schmaljohn CS. DNA vaccines elicit durable protective immunity against individual or simultaneous infections with Lassa and Ebola viruses in guinea pigs. Hum Vaccin Immunother 2017 Dec;13(12):3010-9. http://dx.doi.org/10.1080 /21645515.2017.1382780. PubMed (https://www.ncbi.nlm.nih. gov/pubmed/29135337)

66. Moshkoff DA, Salvato MS, Lukashevich IS. Molecular characterization of a reassortant virus derived from Lassa and Mopeia viruses. Virus Genes 2007 Apr;34(2):169-76. http://dx.doi.org/10.1007/s11262006-0050-3. PubMed

67. Goicochea MA, Zapata JC, Bryant J, Davis H, Salvato MS, Lukashevich IS. Evaluation of Lassa virus vaccine immunogenicity in a CBA/J-ML29 mouse model. Vaccine 2012 Feb;30(8):1445-52. http://dx.doi.org/10.1016/j.vaccine.2011.12.134. PubMed (https://www.ncbi.nlm.nih.gov/pubmed/17143722)

68. Lukashevich IS, Carrion R Jr, Salvato MS, Mansfield K, Brasky K, Zapata J, Cairo C, Goicochea M, Hoosien GE, Ticer A, Bryant J, Davis H, Hammamieh R, Mayda M, Jett M, Patterson J. Safety, immunogenicity, and efficacy of the ML29 reassortant vaccine for Lassa fever in small non-human primates. Vaccine 
2008 Sep;26(41):5246-54. http://dx.doi.org/10.1016/j. vaccine.2008.07.057. PubMed (https://www.ncbi.nlm.nih.gov/ pubmed/18692539)

69. Jahrling PB, Frame JD, Rhoderick JB, Monson MH. Endemic Lassa fever in Liberia. IV. Selection of optimally effective plasma for treatment by passive immunization. Trans R Soc Trop Med Hyg 1985;79(3):380-4. http://dx.doi.org/10.1016/00359203(85)90388-8. PubMed (https://www.ncbi.nlm.nih.gov/ pubmed/3898484)

70. Lukashevich IS, Patterson J, Carrion R, Moshkoff D, Ticer A, Zapata J, Brasky K, Geiger R, Hubbard GB, Bryant J, Salvato MS. A live attenuated vaccine for Lassa fever made by reassortment of Lassa and Mopeia viruses. J Virol 2005 Nov;79(22):13934-42. http:// dx.doi.org/10.1128/JVI.79.22.13934-13942.2005. PubMed (https://www.ncbi.nlm.nih.gov/pubmed/16254329)

71. Lukashevich IS. Generation of reassortants between African arenaviruses. Virology 1992 Jun;188(2):600-5. http://dx.doi. org/10.1016/0042-6822(92)90514-P. PubMed (https://www. ncbi.nlm.nih.gov/pubmed/1585636)

72. Zapata JC, Poonia B, Bryant J, Davis H, Ateh E, George L, Crasta $O$, Zhang Y, Slezak T, Jaing C, Pauza CD, Goicochea M, Moshkoff $D$, Lukashevich IS, Salvato MS. An attenuated Lassa vaccine in SIV-infected rhesus macaques does not persist or cause arenavirus disease but does elicit Lassa virus-specific immunity. Virol J 2013 Feb;10:52. http://dx.doi.org/10.1186/1743-422X-10-52. PubMed (https://www.ncbi.nlm.nih.gov/pubmed/23402317)

73. Carrion R Jr, Patterson JL, Johnson C, Gonzales M, Moreira CR, Ticer A, Brasky K, Hubbard GB, Moshkoff D, Zapata J, Salvato MS, Lukashevich IS. A ML29 reassortant virus protects guinea pigs against a distantly related Nigerian strain of Lassa virus and can provide sterilizing immunity. Vaccine 2007 May;25(20):4093-102. http://dx.doi.org/10.1016/j.vaccine.2007.02.038. PubMed (https://www.ncbi.nlm.nih.gov/pubmed/17360080)

74. World Health Organization. A research and development Blueprint for action to prevent epidemics. WHO; 2018. www.who.int/ blueprint/en/

75. Baize S, Marianneau P, Loth $P$, Reynard S, Journeaux A, Chevallier M, Tordo N, Deubel V, Contamin H. Early and strong immune responses are associated with control of viral replication and recovery in lassa virus-infected cynomolgus monkeys. J Virol 2009 Jun;83(11):5890_
903. http://dx.doi.org/10.1128/JVI.01948-08. PubMed (https:// www.ncbi.nlm.nih.gov/pubmed/19297492)

76. Meulen J, Badusche M, Satoguina J, Strecker T, Lenz O, Loeliger C, Sakho M, Koulemou K, Koivogui L, Hoerauf A. Old and New World arenaviruses share a highly conserved epitope in the fusion domain of the glycoprotein 2, which is recognized by Lassa virus-specific human CD4+ T-cell clones. Virology 2004 Mar;321(1):134-43. http:// dx.doi.org/10.1016/j.virol.2003.12.013. PubMed (https://www. ncbi.nlm.nih.gov/pubmed/15033572)

77. ter Meulen J, Badusche M, Kuhnt K, Doetze A, Satoguina J, Marti T, Loeliger C, Koulemou K, Koivogui L, Schmitz H, Fleischer B, Hoerauf A. Characterization of human CD4(+) T-cell clones recognizing conserved and variable epitopes of the Lassa virus nucleoprotein. J Virol 2000 Mar;74(5):2186-92. http://dx.doi.org/10.1128/ JVI.74.5.2186-2192.2000. PubMed (https://www.ncbi.nlm.nih. gov/pubmed/10666248)

78. Russier M, Pannetier D, Baize S. Immune responses and Lassa virus infection. Viruses 2012 Nov;4(11):2766-85. http://dx.doi. org/10.3390/v4112766. PubMed (https://www.ncbi.nlm.nih.gov/ pubmed/23202504)

79. Walker DH, Johnson KM, Lange JV, Gardner JJ, Kiley MP, McCormick JB. Experimental infection of rhesus monkeys with Lassa virus and a closely related arenavirus, Mozambique virus. J Infect Dis 1982 Sep;146(3):360-8. http://dx.doi.org/10.1093/infdis/146.3.360. PubMed (https://www.ncbi.nlm.nih.gov/pubmed/6286795)

80. Fisher-Hoch SP, Mitchell SW, Sasso DR, Lange JV, Ramsey R, McCormick JB. Physiological and immunologic disturbances associated with shock in a primate model of Lassa fever. J Infect Dis 1987 Mar;155(3):465-74. http://dx.doi.org/10.1093/ infdis/155.3.465. PubMed (https://www.ncbi.nlm.nih.gov/ pubmed/3543155)

81. Johnson KM, McCormick JB, Webb PA, Smith ES, Elliott LH, King IJ. Clinical virology of Lassa fever in hospitalized patients. J Infect Dis 1987 Mar;155(3):456-64. http://dx.doi.org/10.1093/ infdis/155.3.456. PubMed (https://www.ncbi.nlm.nih.gov/ pubmed/3805773)

82. Cohen J. Unfilled Vials. Science 2016 Jan;351(6268):16-9. http:// dx.doi.org/10.1126/science.351.6268.16. PubMed (https:// www.ncbi.nlm.nih.gov/pubmed/26721985) 